\title{
FOREIGN-BORN TEACHING ASSISTANTS AND THE ACADEMIC PERFORMANCE OF UNDERGRADUATES
}

\author{
George J. Borjas \\ Working Paper 7635 \\ http://www.nber.org/papers/w7635 \\ NATIONAL BUREAU OF ECONOMIC RESEARCH \\ 1050 Massachusetts Avenue \\ Cambridge, MA 02138 \\ April 2000
}

I am grateful to Julian Betts, Daniel Hamermesh, and Stephen Trejo for helpful comments, and to the Sloan Foundation for research support. The views expressed herein are those of the author and not necessarily those of the National Bureau of Economic Research.

(C) 2000 by George J. Borjas. All rights reserved. Short sections of text, not to exceed two paragraphs, may be quoted without explicit permission provided that full credit, including $\odot$ notice, is given to the source. 
Foreign-Born Teaching Assistants and the Academic

Performance of Undergraduates

George J. Borjas

NBER Working Paper No. 7635

April 2000

JEL No. I2

\begin{abstract}
$\underline{\text { ABSTRACT }}$
The large literature that analyzes the impact of immigration on the United States typically focuses on measuring the labor market and fiscal consequences. This literature, however, has ignored the impact of immigration on other sectors of society. One sector that is of great interest is the American university, where the share of nonresident aliens in the graduate student population rose from 5.5 percent in 1976 to 10.5 percent in 1996. Despite the rapid growth in the number of foreign students, little is known about their impact on the educational process. Nevertheless, undergraduates frequently complain that the lack of English language proficiency among many foreign-born Teaching Assistants affects adversely their understanding of the material. This paper addresses the question that is at the heart of these complaints: Do foreign-born teaching assistants have an adverse impact on the scholastic achievement of American undergraduates? To provide empirical evidence on this issue, I use data drawn from a survey of undergraduates enrolled in economics principles classes at a large public university. The data suggest that foreign-born Teaching Assistants have an adverse impact on the class performance of undergraduate students.
\end{abstract}

George J. Borjas

Kennedy School of Government

Harvard University

79 JFK Street

Cambridge, MA 02138

and NBER

gborjas@harvard.edu 


\section{FOREIGN-BORN TEACHING ASSISTANTS AND THE ACADEMIC PERFORMANCE OF UNDERGRADUATES}

\section{George J. Borjas}

A large literature analyzes the economic impact of immigrants on the United States (Borjas, 1994). These studies suggest that immigration altered the skill endowment of the labor force, increased the cost of social insurance programs, and widened the wage gap between skilled and unskilled workers. The literature tends to ignore the impact of immigration on other sectors of society. One sector that is of great interest is the American university, where the share of nonresident aliens in the graduate student population rose from 5.5 percent in 1976 to 10.5 percent in 1996 . Foreign students receive a disproportionately high share of the doctorates awarded in many fields. In 1996, nonresident aliens received 23.8 percent of the doctorates in the social sciences; 26.9 percent in the life sciences; 35.0 percent in the physical sciences; and 48.9 percent in engineering (U.S. Department of Education, 1999, Tables 207, 271).

Although it is recognized that the influx of large numbers of foreign students has altered the American university, little is known about the impact of this flow on the educational process itself. ${ }^{1}$ For instance, undergraduates often charge that the lack of English language proficiency among many foreignborn Teaching Assistants affects adversely their understanding of the material. This paper addresses the question that is at the heart of these complaints: do foreign-born teaching assistants have an adverse impact on the scholastic achievement of American undergraduates? To provide empirical evidence on

\footnotetext{
1 Julian Betts and Robert Fairlie (1999) investigate whether immigration induces "crowding out" effects in public schools; Lucy Jacobs and Charles Friedman (1988) present a rare examination of the types of issues that are addressed in this paper.
} 
this issue, I use data drawn from a survey of undergraduates enrolled in economics principles classes at a large public university. The data suggest that foreign-born Teaching Assistants have an adverse impact on the class performance of undergraduate students.

\section{The Setting}

The Principles sequence in economics at a large public university consists of two terms covering micro and macro, respectively. Students can take these two courses in whatever order they like. This university offers two tracks of the sequence, one track uses calculus and the other does not. Students typically take the principles sequence in their freshman or sophomore years.

Both the micro and macro components of the sequence are offered once per term. These classes are held in large lecture halls with the typical class containing about 150 to 200 students. The entire class meets with the professor for about 2.5 hours weekly. Graduate students then serve as teaching assistants (TAs) by teaching an additional weekly session, which reviews material from the professor's lecture and goes over homework assignments. There are six to ten TA sections per principles class, with an average of about 20 students per section. The undergraduate students know the identity of the professor when they enroll in the class, but do not know which graduate students will be teaching the various sections. Undergraduates, therefore, typically choose the TA section that fits most conveniently into their schedule. The assignment of graduate students to the various TA sections is the responsibility of the "Graduate Advisor" in the Economics Department (more on this below). ${ }^{2}$

${ }^{2}$ A TA assigned to the Principles sequence typically teaches two sections in the class. 
All of the TAs assigned to, say, the micro Principles class share in the grading of all micro exams. The professor typically tells each TA to grade a particular subset of the exam for all students in the class, not just those in the TA's section. As a result, it is impossible to attribute grading differences across sections to the fact that different TAs may use different grading scales.

Undergraduate students must complete the Principles sequence prior to taking all other courses offered in the economics department, including intermediate micro (a course required of all economics majors). The typical undergraduate majoring in economics enrolls in intermediate micro upon completing the Principles sequence. As with the Principles sequence, only one intermediate micro class is offered in any given term.

I conducted a survey of undergraduate students enrolled in the intermediate micro class. ${ }^{3}$ The survey asked the students about their experiences in the two-semester Principles sequence. The students reported if the TA in each class of the sequence was foreign-born, the final grade in each of the classes, their overall GPA, and other background variables. A total of 309 questionnaires were collected during the sample period, and 75 percent of these questionnaires contained complete information on the key variables used in the study. The analysis reported below is based on the subset of questionnaires that provided the relevant data.

\section{Results}

Table 1 summarizes the data provided by the survey. About 34 percent of the students in the micro principles class and 44 percent of the students in the macro principles class had a foreign-born

\footnotetext{
3 The survey was conducted in three intermediate micro classes taught in three separate academic years during the mid-1990s. The survey instrument is available from the author.
} 
TA. The table reports the average final grade in each of the principles classes (about 3.1) as well as the overall GPA of students in the survey. All grades are measured on a 0-4 scale (where an A gets 4 grade-points, an A- gets 3.7 grade-points, a $\mathrm{B}+$ gets 3.3 grade-points, etc.).

The survey asked two questions about the "quality" of education provided by foreign-born TAs. The undergraduates commented on whether foreign-born TAs had better or worse communication skills than their native-born counterparts, and on whether foreign-born TAs were better or worse prepared. The overwhelming majority of undergraduates (nearly 80 percent) reported that foreign-born TAs have worse communication skills than the native-born. The assessment of the class preparation of foreignborn TAs was more favorable: there is almost no difference between native- and foreign-born TAs. The regression model used in the study is given by:

$$
G_{i}=\beta F_{i}+\text { other variables, }
$$

where $G_{i}$ is student $i$ 's final grade in one of the principles classes, and $F_{i}$ is a dummy variable set to unity if the student had a foreign-born TA in that particular class. The data for the micro and macro principles are stacked, and dummy variables are included to indicate which class the data are drawn from, as well as to indicate if the student was in the "math track."

Table 2 shows that undergraduate students enrolled in sections taught by a foreign-born TA receive lower final grades. ${ }^{4}$ After controlling for a student's overall GPA, a foreign-born TA reduces the

\footnotetext{
${ }^{4}$ I also estimated the regressions separately for the micro and macro Principles classes and obtained similar results. If the regression on the final grade in the micro (macro) class includes the background of the TA in the micro (macro) class and the background of the TA in the macro (micro) class, the wrong variable is not statistically insignificant. For example, the coefficient of the correct TA variable in the micro class regression is -.209 (standard error of .089), while the coefficient for the wrong TA variable is .022 (.083). In the macro class regression, the correct TA coefficient is -.327 (.082), and the wrong coefficient is -.022 (.086).
} 
scholastic achievement of undergraduates by .2 grade points. Because the survey provides information on two class grades per student (i.e., the grades in micro and macro principles), the regression can add student-specific fixed effects. This fixed effect specification effectively controls for all student-specific variables, including ability and effort, which have a similar impact on the student's performance in each half of the sequence. Column 3 reports the fixed-effect regression. The scholastic achievement of a particular undergraduate declines if he or she were to switch from a section taught by a native-born TA to one taught by a foreign-born TA. A foreign-born TA still reduces the final grade in the course by about .2 grade points.

To determine if the quality of education provided by foreign-born TAs (as measured by communication skills and class-preparedness) explains the poor achievement of students enrolled in sections taught by these TAs, I expanded the regression specification. Column 4 of the table interacts the foreign-born indicator with the student's assessment of the communication skills of foreign-born TAs. Foreign-born TAs reduce academic achievement more among those students who provide a negative assessment of their communication skills (but the difference between the two coefficients is not statistically significant).

Column 5 interacts the foreign-born TA dummy with the undergraduate's perception of the class-preparedness of foreign-born TAs. The evidence indicates that foreign-born TAs do not worsen the scholastic achievement of undergraduates if they are better prepared than native-born TAs. It seems as if additional class preparation may resolve the teaching difficulties encountered by foreign-born TAs. The evidence, therefore, is at least suggestive of a correlation between the quality of education provided by foreign-born TAs and the class performance of undergraduates. 
Finally, it is instructive to examine the interaction between the nativity status of the TA and the nativity status of the undergraduate student. About a quarter of the undergraduate students in the survey were born outside the United States. I estimated the regression separately in the sample of U.S.-born and foreign-born undergraduates. As the last two columns of Table 2 show, foreign-born TAs have an adverse impact on the educational achievement of U.S.-born undergraduates, but do not lower the final grade of foreign-born undergraduates. It seems as if the language barriers introduced by the foreignborn status of graduate teaching assistants affect only the educational attainment of American-born undergraduates.

The survey data indicated that most of the foreign-born undergraduates were of Asian origin. Although the survey did not collect information on the ethnic background of the TAs, casual observation of the graduate student body indicated that most of the foreign-born TAs were also of Asian origin. The evidence suggests that foreign-born graduate students do not have an adverse impact on the academic achievement of undergraduate students who are "like them"- perhaps both in terms of language and culture- - but do have an adverse impact on undergraduates who are sufficiently different.

\section{Discussion}

A number of problems arise if one wishes to interpret the evidence as a causal relationship between the education provided by foreign-born TAs and the academic performance of American undergraduates. The first involves the way in which the graduate students were assigned to the different TA sections. As was noted earlier, a Graduate Advisor (typically a senior faculty member) assigns the graduate students to various undergraduate classes. 
There is no formal description of how this assignment is made, but English proficiency is one of the factors that the Advisor considers when assigning graduate students to the Principles sequence. Graduate students with worse-than-average communication skills are often assigned to upper-division classes (such as Labor Economics or Public Finance) where the TA does not hold a weekly teaching section with the class, but instead helps mainly with grading. The assignment of the graduate students who have better-than-average communication skills to sections in the Principles classes suggests that the negative correlation documented above may understate the adverse impact of foreign-born TAs on the achievement of American undergraduates.

Undergraduates may also not want to enroll in sections run by foreign-born TAs. ${ }^{5}$ This problem is analogous to the one that plagues the literature measuring the impact of immigrants on the native labor market. In that literature, it is typically found that natives residing in "immigrant" cities (i.e., cities where many immigrants reside) are only slightly worse off than natives residing in "native" cities. This weak correlation, however, may mask the true impact of immigration on the labor market, because natives respond to the entry of immigrants by voting with their feet. As native workers move out of immigrant areas (or avoid moving into those areas), they diffuse the negative impact of immigration over the entire economy. To the extent that undergraduates can migrate across sections, much the same process would be observed at a typical university. Sections taught by foreign students would empty out, and those taught by native students with better communication skills would fill up, presumably diluting the positive impact of native-born TAs. The negative correlations documented in this paper would underestimate the true impact of foreign students on undergraduate scholastic achievement.

\footnotetext{
5 Note also that only those undergraduates who took the Principles sequence and went on to take intermediate micro theory completed the survey.
} 
It is unlikely that undergraduates enrolled in the Principles sequence at the university under study can migrate freely across sections. Scheduling conflicts restrict choice. There are also physical constraints on the size of the rooms assigned to TA sections (the rooms typically do not hold more than 30 students). Finally, the undergraduate student may wish to maintain some link with the section in which he or she is enrolled because the exams are typically returned to the student during the TA section.

\section{Conclusion}

It is important to stress the limitations of this study. The analysis is based on the academic performance of students in one class (the Principles sequence) in one field (Economics) at one public university. Despite the frequent complaints that American undergraduates make about the quality of education they receive from foreign-born Teaching Assistants (and instructors), the results presented in this paper cannot be generalized to other fields and other institutional settings. The evidence suggests, however, that the undergraduate complaints might have a basis in fact and indicate the need for more extensive study of this important question. 


\section{REFERENCES}

Betts, Julian and Robert W. Fairlie. "Does Immigration Induce 'Native Flight' from Public

Schools Into Private Schools?” Working Paper, Public Policy Institute of California, 1999.

Borjas, George J. “The Economics of Immigration.” Journal of Economic Literature

December 1994, 32(4), pp. 1667-1717.

Jacobs, Lucy Cheser and Charles B. Friedman. "Student Achievement under Foreign Teaching Associates Compared with Native Teaching Associates," Journal of Higher Education

September/October 1988, 59(5), pp. 551-563.

U.S. Department of Education, Digest of Education Statistics 1998. Washington, DC: U.S.

Government Printing Office, 1999. 
TABLE 1

\section{SUMMARY CHARACTERISTICS OF SURVEY DATA}

Variable

Final grade in class

Foreign-born TA (\%)

Math track (\%)

Overall GPA

Communication skills of foreign-born TAs (\%):

Better than natives

Worse than natives

Same as natives

Preparation of foreign-born TAs (\%):

Better than natives

Worse than natives

Same as natives $\underline{\text { Micro Principles }}$

3.15

34.1

25.4

3.03

1.3

79.2

19.5

15.1

15.6

69.3

232
Macro Principles

3.07

43.9

20.0

3.05

1.3

78.2

20.4

14.3

15.2

70.5

Number of observations 230 
TABLE 2

\section{THE IMPACT OF FOREIGN-BORN TEACHING ASSISTANTS ON SCHOLASTIC ACHIEVEMENT}

\begin{tabular}{|c|c|c|c|c|c|c|c|}
\hline \multirow[b]{3}{*}{ Independent variable: } & \multicolumn{7}{|c|}{ Sample of undergraduates } \\
\hline & \multicolumn{5}{|c|}{ All undergraduates } & \multirow{2}{*}{$\begin{array}{c}\begin{array}{c}\text { Native- } \\
\text { born }\end{array} \\
(6)\end{array}$} & \multirow{2}{*}{$\begin{array}{c}\begin{array}{c}\text { Foreign- } \\
\text { born }\end{array} \\
(7)\end{array}$} \\
\hline & $\underline{(1)}$ & $\underline{(2)}$ & (3) & (4) & $\underline{(5)}$ & & \\
\hline Foreign-born TA & $\begin{array}{l}-.193 \\
(.065)\end{array}$ & $\begin{array}{l}-.231 \\
(.058)\end{array}$ & $\begin{array}{l}-.214 \\
(.076)\end{array}$ & --- & --- & $\begin{array}{l}-.284 \\
(.080)\end{array}$ & $\begin{array}{l}.043 \\
(.189)\end{array}$ \\
\hline \multicolumn{8}{|l|}{ Foreign-born TA interacted with: } \\
\hline $\begin{array}{l}\text { Foreign-born TAs have worse } \\
\text { communication skills than } \\
\text { natives }\end{array}$ & --- & --- & --- & $\begin{array}{l}-.218 \\
(.083)\end{array}$ & --- & --- & --- \\
\hline $\begin{array}{l}\text { Foreign-born TAs have same/ } \\
\text { better communication skills }\end{array}$ & --- & --- & --- & $\begin{array}{l}-.100 \\
(.204)\end{array}$ & --- & --- & --- \\
\hline $\begin{array}{l}\text { Foreign-born TAs are worse } \\
\text { prepared than natives }\end{array}$ & --- & --- & --- & --- & $\begin{array}{l}-.174 \\
(.167)\end{array}$ & --- & --- \\
\hline $\begin{array}{l}\text { Foreign-born TAs are equally } \\
\text { prepared }\end{array}$ & --- & --- & --- & --- & $\begin{array}{l}-.279 \\
(.092)\end{array}$ & --- & --- \\
\hline $\begin{array}{l}\text { Foreign-born TAs are better } \\
\text { prepared }\end{array}$ & --- & --- & --- & --- & $\begin{array}{l}-.012 \\
(.234)\end{array}$ & --- & --- \\
\hline Math track & $\begin{array}{l}-.026 \\
(.076)\end{array}$ & $\begin{array}{l}-.143 \\
(.068)\end{array}$ & $\begin{array}{l}-.464 \\
(.140)\end{array}$ & $\begin{array}{l}-.509 \\
(.145)\end{array}$ & $\begin{array}{l}-.478 \\
(.142)\end{array}$ & $\begin{array}{l}-.384 \\
(.158)\end{array}$ & $\begin{array}{l}-.656 \\
(.286)\end{array}$ \\
\hline Overall GPA & --- & $\begin{array}{c}.786 \\
(.068)\end{array}$ & --- & --- & --- & --- & --- \\
\hline $\begin{array}{l}\text { Includes student-specific fixed- } \\
\text { effects }\end{array}$ & No & No & Yes & Yes & Yes & Yes & Yes \\
\hline R-squared & .029 & .248 & .735 & .738 & .740 & .765 & .682 \\
\hline Number of observations & 462 & 462 & 462 & 451 & 449 & 349 & 109 \\
\hline
\end{tabular}

